\title{
Challenges of Christian Missionary Education in Igboland, Nigeria: Focus on the Impediments Affecting the Catholic Primary School Projects (1885-1970)
}

\author{
Peter U. IWUNNA Ph.D \\ Department of Educational Foundations, University of Nigeria, Nsukka Enugu State, Nigeria. \\ Ndukwu Eric Chima. Ph.D. \\ (Correspondence Author) \\ Department of Educational Foundations, University of Nigeria, Nsukka \\ Dioka, Bridget O. \\ Center for African Studies, University of Nigeria, Nsukka \\ Joel O. ALISON \\ Department of Educational Foundations, \\ Nnamdi Azikiwe University, Awka, Anambra State, Nigeria. \\ Orifamah, Daniel \\ Post Primary Education Board Isoko, Delta State.
}

\begin{abstract}
This paper discusses the key problems which militated against the Catholic missionary education in Igboland, Southeast Nigeria. It analyses the key problems which clogged against the mission's educational enterprise in Igboland which is predominantly Christian, while the Catholic Mission remained the dominant force in its educational landscape. Because of its affinity with a greater majority of the Igbo population, and acceptance by local most communities, Catholicism became synonymous with the Igbo, with the effect that the mission's educational space became so wide and could be found in most local towns and villages. As it were, this development fertilized the stage for the emergence of numerous thorns along the track with the effect that the quality of its primary school education was impacted, while its ability to spread to all towns and villages suffered setbacks. Meanwhile, the undue competitions and struggle for space and population between the mission and other Christian missions in towns and villages involved in the Igbo educational project became an added factor. It is the conclusion of this paper that faced with the weight of the militating factors, the mission's educational project suffered setbacks in a number of areas.
\end{abstract}

Keywords: Catholic; Christian Missionary; Education; IgboLand; Primary School.

DOI: $10.7176 / \mathrm{JEP} / 12-29-10$

Publication date:October $31^{\text {st }} 2021$

\section{Introduction}

As it were, the project of the Catholic or Christian missionary education in Igboland and other parts of Nigeria during the colonial era, as well as the post-civil war years, encountered numerous bottlenecks. Its routes towards a healthy growth were literally riddled with thorns and situational landmines, with the effect that some of the desired goals behind the initiation of the project suffered setbacks and experienced stunted growth. Largely unprepared as the missionaries were, their targets of transplanting the seeds of Western education and its literacy related cousins onto the yearning soils of Igboland, witnessed numerous forms of drought from the days which followed, after the arrival of the Catholic missionaries on the great shores of the River Niger at Onitsha, on $5^{\text {th }}$ December, 1885 (Omenka, 1989; \& Iwunna, 2009).

Undaunted by the enormity of the situational traumas which attempted to thwart their efforts to introduce the Igbo to the arts of literacy, and wholesomely pressured by the need to propagate the seeds of the Christian religion in order to turn the people's religious beliefs around, no mountains and hills proved insurmountable. Dogged efforts were put in place to push ahead with their projects of educating the people, in an attempt to impact their attitudes, beliefs, mindsets, and professions, etc. Thus, the primary target of this text is to discuss some of the key problems which attempted to sniff away the Catholic Mission's efforts to provide Western education to the Igbo, southeast Nigeria. Renowned as the dominant Christian mission in the Igbo educational project, the involvement of other Catholic missions impacted the uprooting of some of the thorns which grew along the road to the education of the people (Omenka, 1989).

This analysis shall be made in two major phases. In the first phase, I shall provide some historical narrative 
on the arrival of the Catholic Mission, as well as the other Christian missions on the shores of Igboland. Along the line, attempts shall be made to underpin some of the key elements which necessitated the engagements of the Christian missions in this project. The second phase shall focus clearly on the numerous problems which prevailed against the growth of the Christian missionary education in parts of Igboland.

As it were, the period of 1885-1970, represents an era of dramatic developments in Igboland's educational history. The historic year of 1885 marked the arrival the Catholic Mission in the Igbo area, which marked the injection of a new blood in the spread of Western education, through the continued erection of schools in nooks and crannies of Igboland. That was an era when Christian missionaries took a frontal lead in the development of the educational sector, which regrettably ended with the end of the bloody civil war in 1970 when schools were pulled away from the hands of the various missions and voluntary agencies.

\section{Historical overview}

The town of Onitsha, located in the present Anambra State, remains a colossus in the history of the Igbo Catholicism and the educational conquest of Igboland by the Catholic Mission in collaboration with the other Christian missions. Because of its strategic location at the shores of the River Niger, its navigational routes and commercial base provided the necessary inroads into the numerous towns and villages across its borders. It played foremost hosts to the different Christian missions who arrived in Igboland, as well as served as a key commercial base for European firms located in the southeast of Nigeria (Iwunna, 2011).

History informs us that the Catholic Mission, under the leadership of Rev. Fr. Lutz, a French missionary, led a team of other missionaries into the riverine town of Onitsha on $5^{\text {th }}$ December, 1885 . Prior to this event, a British commercial firm known as the Royal Niger Company had acquired the sole rights to conduct commercial and administrative activities on behalf of their home government in the Niger areas. Empowered by this mandate, the company gained firm monopoly over all trade and commercial activities within the territory. The company was also mandated to handle all matters of political governance on behalf of the British government, as well as controlled the commercial activities of other European firms who wished to establish bases within the territory (Omenka, 1989; \& Country Studies, 2009).

Even in these millennium years, Onitsha is still prided as the heartland of the Igbo Catholicism and the Ireland of Nigeria, which is in appreciation of its role as the foremost host of the earliest missionaries, from where they scattered into towns and villages far and near. As they sojourned, they continued to consolidate their presence in different towns and villages, and established schools, churches, and other literacy centres. Meanwhile, the contributions of the earlier educated indigenes of Onitsha, who served as teachers, catechists, interpreters, and messengers, impacted the activities of missionaries in their attempts to educate and evangelize the Igbo.

Motivated by the services of the available local personnel earlier trained by the CMS, the Catholic Mission was able to penetrate deeper and deeper beyond the Onitsha areas into key Igbo towns as Atani, Aguleri, Ntedje, Obosi, Awka, Nnewi, Owerri, Mbaise, Nkwere, Aba, Bende, Arochukwu, Ogidi, Nsugbe, Ogbunike, etc. (Iwunna, 2009, p. 38; Ekechi, 1996, pp. 130-131; \& Kalu, 1970). For instance, Fr. John Cross Anyaogu, who was ordained a Catholic priest on $8^{\text {th }}$ December, 1930, and Fr. Michael Iwene Tansi, who also became a Catholic priest on $19^{\text {th }}$ December, 1937, who were both indigenes of Onitsha are clear examples. Thus, the role of Onitsha as the birthplace of the Catholic faith in Igboland, as well as the contributions of its sons and daughters in the education and conversion of the Igbo remains a significant factor of history (Ekechi, 1972; \& Nwosu, 1982).

However, history gladly appreciates the fact that the Catholic Mission was a late arrive into the Igbo Christian missionary enterprise. As it were, prior to its arrival, the CMS team, led by Bishop Adjai Crowther, a former slave of Yoruba origin, had entered Onitsha in July, 1857. With the advantage of its earlier arrival, it enjoyed the privilege of establishing a couple of schools and missionary outposts around the commercial city of Onitsha, which included Asaba, Alonso, Abo, Obosi, and Awka areas. In addition, it also enjoyed the privilege of occupying some of the choicest parcels of land around the area, as well as positioned itself at the point of stiff missionary rivalry in parts of Igboland. These were in addition to its knowledge of the local geography of a number of towns and villages (Nwosu, 1982; Omolewa, 1986; Ekechi, 1996; \& Iwunna, 2009).

Additionally, the Presbyterian Mission, which was led by Rev. Hope Masterton Waddell, was not left out in the missionary conquest of the Igbo. Earlier, this mission crossed into the Igbo territory from Calabar, in April 1846. With the gesture of a piece of land at hand, offered by King Eyamba of Duke Town, the muzzle to erect the famous Hope Waddell Training Institute, which was a technical training school was initiated. From its Calabar headquarters, its educational and missionary tentacles spread into neighbouring Igbo towns such as Afikpo, Ngwa, Aba, and Arochukwu, etc. (Macrae, 1956).

One cannot exhaust this discussion if we neglect the inputs of the other Christian missions who were also involved in the Igbo missionary project, which includes the Primitive Methodist Mission, which arrived Uzuakoli in 1910, the Qua Iboe Mission, whose date of arrival was 1887, the Adventist Mission, the Sudan United Mission, Sudan Interior Mission, and the Apostolic Church of Christ, whose activities also impacted the 
missionary development of Igboland. In all these cases, the establishment of schools and other literacy centres, as well as mission outlets formed key priorities (Kalu, 1986; \& Omolewa, 2008).

Thus, following the death of Monsignor Leon Lejeune in 1905, and replacement by Monsignor Joseph Shanahan, the Catholic Mission's policy of evangelization through education received a new blood. The pursuit of education as a major missionary activity was pursued with vigour, while the establishment of schools and educational institutions received primary attention. To that effect, Catholic schools were opened in different nooks and crannies of Igboland. Teacher training colleges, whose products manned the mission's schools and educational institutions were erected. Seminaries which trained its priests and nuns were also established, as well as secondary schools, technical colleges, domestic science centres, and other tertiary institutions which serviced the mission's local personnel needs came to life.

Space constraints cannot allow me to draw a large list of these educational landmarks. However, a few educational institutions need to be mentioned, which include the College of the Immaculate Conception (CIC), Enugu, 1940; Queen of the Holy Rosary College (QRC), Enugu, 1942 (later transferred to Onitsha in 1949); St. Patrick's College, Emene, 1956; St. Peter's College, Achina; St. John's college, Alor, 1958; Our Lady's College, Nnobi, 1959; Community Grammar School, Amuzi, 1962; All Hallows Seminary, Onitsha, 1952; St. Peter Claver's Seminary, Okpala Aba, 1951; St. Paul's Seminary, Eke, 1934; Bigard Memorial Seminary, Enugu, 1950, and so on. There were also the Congregation of the Handmaids of the Holy Child Jesus (1931), and the Immaculate Heart of Mary (1937), which trained its nuns (Iwunna, 2009). In the areas of healthcare services too, the Catholic Mission showed commitments too. Among others, it established the Holy Rosary Maternity, Onitsha (1935); Mount Carmel Hospital, Emekuku, September, 1935; St. Joseph's Hospital, Adazi, 1939; Our Lady of Lourdes Hospital, Ihialla; Mother of Christ Maternity Hospital, Enugu, and the Borromeo Hospital Onitsha, all of which were born between 1937 and 1940 (Ekechi, 1989).

In the areas of teacher education, the mission's investment interests were never found wanting too. Records credit the following institutions to its dedication to the educational empowerment of the Igbo: Lorreto Training College, Adazi, 1939; Holy Rosary College, Enugu, 1943; Mount Carmel College, Emekuku, 1943; St. Martin's Training College, Ihialla, Bishop Shanahan Training College, Orlu, 1948; Holy Ghost Training College, Umuahia, 1948; Teacher Training College, Agulu, 1949; Teacher Training College, Nsukka, 1951; Teacher Training College, Iwollo, 1959; St. Patrick's Training College, and Ogbe Ahiara, 1956; St. Joseph's Training College, Aba, 1949, Women's Training College, Ogbor Nguru, 1948, and so on (National Archives, Enugu 1944; Ozigbo, 1985; \& Iwunna, 2009). In comparison with the other Christian missions involved in the Igbo project, these landmarks explain the Catholic Mission's leading position in the educational development of Igboland, putting into context its number of schools, learners' enrolment figures, geographical spread, and general impact on the overall life of local communities.

\section{The White Man's Dilemma and its Crippling Effects}

We are now faced with the task of discussing the major problems which impacted the educational activities of the Catholic Mission, as well as all the other Christian missions in parts of Igboland. This is an attempt to underline the fact that the project of spreading Western literacy through schools in parts of Igboland, was clogged by several obstacles, whose impact affected the targeted objectives of the colonial authorities of Britain and their missionary allies. Under the following subheadings, I shall discuss the key problems encountered by this project, as well as their effects on the educational system. Thus, largely unprepared as the missionaries were, the task of meeting up with the ever growing demands of the educational projects proved hectic, and often threw the missions into a frenzy of dilemmas, with the effect that the attitude of improvisation became an acceptable norm. They were as follows:

\section{Finance}

The story that lack of adequate financial backbone made enormous impact on the educational visions of the Catholic, as well as all the other Christian missions, formed an open secret in the colonial attempts to effectively transplant the seeds of Western education on the rich soils of Igboland. As is natural, inadequate financial capabilities weigh down the growth of any persons or businesses. Naturally then, lack of necessary financial powers dilapidate growth, and checkmate abilities to forge ahead with full confidence of oneself.

Thus, owing to enormity of this predicament, Christian mission schools' abilities to deliver quality education suffered setbacks. Abilities to supply the relevant teaching and learning materials often met failures. Poor salaries, often categorized as stipends by authors, became the monthly take-home slogans of teachers and other mission employees (Phillipson, 1948; Seghers, 2004 August; Depaepe, Debaere, Van Rompaey, 1992 \& Ugwu \& Nwamuo, 1998). Mission schools and other literacy centres continued to operate in miserable conditions, while teachers and other local personnel fought hard wars to meet their individual family needs (Ogoko, 2006; \& Osokoya, 2015).

As well, majority of mission schools operated without proper supervision, owing to the lack of adequately 
trained personnel who could conduct the exercise, with the effect that teachers' activities often remained unmonitored. Their performances in classrooms could not be properly evaluated, while adherence to the curricula often became questionable.

Based on these situations, we are faced with the question: What were the mission's sources of funds, and how did they influence its financial dispositions? In order to address this question, we briefly arrive at the agreement that the British government's annual grants in aid, host community financial contributions, motherchurch support, and tuition fees, formed their basic sources of funds. Because of space constraints, a brief description of each source shall suffice for now.

First and foremost, it was the official policy of the British colonial government to provide some level of fixed financial assistance to all approved mission schools and voluntary agency schools within the Nigerian territory. As the government in power, it saw the supply of education as its responsibility, and therefore offered to support schools with certain amounts of money, which aided them manage the financial needs of their schools. On the basis of this commitment, its interests and involvement in the educational sector remained strong, while it supervised the activities of the schools, as well as monitored their curricula (Phillipson, 1948; \& Odo, Ede, \& Ezike, 1996). One major implication of this collaboration was that schools developed rapidly in parts of Igboland.

The second factor was that host communities supported mission schools located within their territories with community-generated funds. As was the case, majority of such funds were raised through mandatory levies, and community harvest, (locally known in the Mbaise areas as 'iwu mkwu' or 'nkuchi mkwu') of all ripe oil palm fruits within the confines of their boundaries. In addition, individual community members made generous donations to mission schools located within their communities (Afigbo, 2001).

Importantly too, periodical financial support from Rome which was the Catholic Mission's headquarters, impacted the course of missionary education in Igboland. As the mother-church, it assisted the mission manage the huge financial commitments demanded for the prosecution of its educational projects. Authors describe it as the "Mission central funds" (Phillipson, 1948; \& Omenka, 1989). This was in addition to the tuition fees charged pupils and students in its schools all over the land, designed to assist the mission shoulder the huge financial demands involved in the running of schools, most especially the un-assisted ones which never qualified for the government's annual grants in aid (Phillipson, 1948; \& Omolewa, 2001).

Thus, we could underline a few major factors. With the story of financial handicap in focus, it could be understood that the missionaries were largely unprepared before they ventured into the project of education. Among others, their involvement in this sector was necessitated by the need to establish the needed foundations for the evangelization of the people, as well as train local workforce who could be recruited into the different sectors of the mission. Putting these into context, one is not in any doubt about the need to arm the people with some level of literacy, in order to prepare them for the numerous tasks demanded by the mission's numerous projects.

\section{Pupils' Irregular Attendance}

It goes without saying that irregular attendance formed one of the key problems faced by mission schools in parts of Igboland, and other parts of Nigeria. As it were, this factor was promoted on the strength that majority of parents did not yet appreciate the relevance of education to the lives of their children and family members. They remain ignorant of the value of regular school attendance towards the educational empowerment of these young members of the society.

Instead of encouraging them on the areas of punctuality and regularity of school attendance, such parents rather derived selfish pleasure in keeping children away from schools on the basis of personal reasons. Thus, among the Igbo, it was quite uncommon that on certain market days, children of some parents were withdrawn from attending schools, in order to assist their parents in the farm, at the market stalls, or the performance of specific domestic chores, which had devastating effects on their performances at school (Taiwo, 1980). It was not out of place then that mission schools recorded lower attendances on certain market days of the week, while the reverse was the case on other days.

\section{Poor Educational Infrastructure}

It was an open secret that majority of mission schools in Igboland were mere empty shells, and operated without adequate and healthy structures which could enhance teaching and learning. Without paying due attention to the supply and availability of basic educational infrastructures, mission schools often operated in improvised structures such as church halls, under tree sheds, community meeting halls, and open grounds which rather impeded teaching and learning. Often, poorly set mud walls, with rough floors and leaking mat roofs served as school classrooms for Christian missions. It goes without saying then that majority of the schools were opened without permanent school blocks in place, while the necessary ventilation, proper sanitation facilities, as well as recreation grounds were unavailable (National Archives Enugu, 1925; \& Osokoya, 2015).

As was often the case, majority of those schools did not have enough desks, chairs, tables, exercise books, 
textbooks, pens and pencils, chalkboards, etc. Because of these deficiencies, pupils in the lower classes often received their lessons while seated on uncomfortable positions in the hard floors of their classrooms. On the part of teachers, moulded blocks, often served as their tables and stools, while the walls of classrooms were converted into chalkboards (Iwunna, 2009b; \& Onah, 1998).

\section{Inadequate Training for Teachers}

The area of poor teacher education was another crippling dimension in the wheels of the Catholic missionary project in Igboland. As it were, majority of mission employed teachers were either totally un-trained or did not receive adequate formal teacher education, which prepared them for posting to schools. As untrained as they were, their state of professional unpreparedness naturally impacted their ability to perform at school. Their lack of training placed a wide wedge on their abilities to deliver and handle classroom activities in some professional manner (Iwunna, 2010; \& Fafunwa, 1974). As well, their ability to understand the core elements of classroom activities, most especially in the areas of lessons handling were quite inadequate.

Because of their lack of training, the mission categorized them as 'un-certificated teachers'. In some cases, they were addressed as pupil-teachers, catechist-teachers, or bush school teachers. But in some polite language, they were also known as un-trained teachers. Because of their lack of training, this category of teachers was generally posted to the un-assisted list of mission schools, which were usually located in remote Igbo villages, and far from unnecessary attention of the government. Because the schools of their posting belonged to the mission's list of un-approved schools, this class of teachers were so poorly remunerated, but largely overworked (Fafunwa, 1974). However, the dire unavailability of adequate numbers of trained teachers for posting to schools largely impacted this improvisation exercise, which was a sort of relief project in the hands of the mission.

Regrettable as it was, these un-trained teachers often enjoyed the privilege of receiving some kinds of induction courses or impromptu trainings from the hands of their trained colleagues who passed through formal teacher training institutions. At times, headmasters, and even church catechists offered short-term training weekend or after-school training exercises. In some cases, they received periods of apprenticeship or on-the-job training from the hands of their trained colleagues. Inadequate as these were, the affected teachers could hardly deliver what they did not receive. Their performances were often much below the average mark (Fafunwa, 1974; \& Iwunna, 2011).

The situation was not so much different for those who managed to attend teacher training colleges. As it were, some of the training colleges did not have the necessary teaching and learning materials needed for proper teacher education. Some of them operated without approved textbooks, while the classroom basic facilities were in short supply. Simply put, these situations are clear indicators to the lack of adequate funding and governmental support suffered by mission schools in Igboland and other parts of Nigeria (Omolewa, 1986; Nwosu, 1990; \& Iwunna, 2009).

\section{Ineffective Supervision of Schools}

The area of schools' supervision was another major area of setback for the Catholic missionary educational project. As we already indicated, the mission lacked the adequate numbers of trained teachers who could be deployed to its growing number of schools. Added to this factor was the mission's lack of trained and qualified supervisors of schools. The effect of this development became so dilapidating that school teachers who possessed some years of teaching experience were improvised as school inspectors.

Because the mission-appointed officers lacked the basic professional experiences which prepared them for the job of supervising schools, this area of education suffered failures. Their lack of professional training impeded their abilities to handle the job properly, most especially in the areas of supervising large numbers of teachers and pupils, handling of schools' financial books, monitoring of schools administrative matters, as well as the effective handling of staff welfare matters (Iwunna, 2009b; \& Osokoya, 2015). Because of their lack of training, the expertise needed to really translate the British government's policy of colonial education to the various local contextual situations, areas of need, occupational settings, cultures and traditions, geographical settings, and natural environments of communities could not meet the anticipated objectives.

As a result, mission schools continued to follow educational curricula which were quite less relevant to local situations and community needs. Rather, their lack of supervisory training blinded them from removing the chaffs from the grains, which compelled them to swallow curricula contents whole and entire, to the detriment of learners. The end result was that Europe-based educational curricula were rather prioritized and consequently occupied the higher strata in the considered order of relevance in educational activities. At the end of the day, mission school graduates became much less educated, less creative, intellectually questionable, and literally incompetent. School leavers turned out as bye products of the culture of educational consumerism (Zachernuk, 1998; \& Iwunna, 2011).

There were other implications associated with this dilemma. Among others, because of the inadequate number of schools' supervisors, the activities of several mission schools were never monitored year in year out. 
The number of schools on the un-assisted list grew so dramatically. Teachers' activities were not monitored, with the effect that majority of them lacked the professional skills required for the handling of classroom activities. The result was that teachers began to be conceived as demi-gods and only source of academic knowledge, while the activities of teaching and learning remained a "one-way traffic", whereby learners functioned as mere consumers of imperial cultures (Depaepe, 2008; \& Osokoya, 2015).

\section{Cultural and Traditional Influences}

It goes without saying that the Igbo attachment to local cultures and traditional values also impacted the growth of missionary education in parts of Igboland. Like other Nigerian language groups, the Igbo world is highly patriarchal and totally male-dominated. Based on the strength of these unwritten natural laws, the male children take preeminent positions in majority areas, and most importantly in all matters of decision making on issues concerning the welfare of their families and community members. The indigenous values and traditional practices of the people offered enormous prerogatives to the males over their female partners, children, and wards. With a direct focus on education, let us briefly examine how this value system affected the missionary efforts at providing Western education to the Igbo.

At the onset, there were lots of negative feelings against the model of education offered by Christian missionaries and their agents. It was the clear understanding of the Igbo that the white man's model of education pirated by Christian missionaries was a direct negation of its indigenous values and traditional ways of seeing life in its true nature (Fafunwa, 1974). In their minds, it was the white man's deliberate ploy to deny the Igbo their genuine identity, destroy their value system, and pollute learners with whatever values that served colonial needs. Because of this strong bias, most parents remained sceptical about sending their children and wards to schools. Among parents, this was a replication of an attitude of rejection of the foreign model of education and its influences (Omolewa, 1986).

Igbo parents' scepticism about the Western model of education emanated from their fear of the negative effects which their knowledge exposed learners to, which included the rejection of traditional dressing cultures, modes of religious worship, belief system, food culture, social relationships, etc. For parents, it was thought that Western education promoted abuse of indigenous values, social decadence, moral corruption, sexual promiscuity, kin group disintegration, and rejection of family norms (Omolewa, 1986; \& Fafunwa, 1974). On the basis of these factors, majority of Igbo parents resisted the idea of enrolling their children and wards into schools, while on the part of female children, the Igbo culture of male preference tended to complicate the matter. Based on these culture-based factors, mission schools suffered terrible setbacks, as enrolments continued to dwindle in most schools. However, in the course of the years, the situation changed dramatically as the bounties associated with literacy began to arrive in Igbo homes and among family members.

\section{Biafra/Nigeria Civil War}

Mission school education was one of the key areas of devastation where the ground shaking guns of the Biafra/Nigeria bloody civil war left its ugly footprints on the sands of history. This was a war of secession when the Igbo of the oil-rich southeast of the country attempted to establish an independent state of their own, away from the rest of Nigeria. The bloody civil war, which started in 1967, raged on until late January, 1970 when it finally ended during the military regime of General Gowon. With the three R's (Reconciliation, Rehabilitation, and Reconstruction), the federal government initiated a number of nation building programs which were intended to mend wounds and reconcile broken ties (Madiebo, 1980).

As was the case, the outbreak of the civil war left mission schools in a sober state. The massive airpower of the Nigerian government burnt down business ventures, demolished schools, destroyed school infrastructure, and forced able bodied teachers and pupils into the war front. Again, the war, which was fought on the soils of Igboland forced countless thousands of innocent citizens, including young school children, parents, and teachers, to their early graves. Hospitals and maternities were not even spared. Teachers were forcefully drafted into the army. Meanwhile, schools and educational facilities were channelled to the prosecution of the war efforts, thereby undermining the educational needs of the war-affected Igbo. The ugly result was that schools were forced to close down for fear of children's safety (Iwunna, 2003; \& Iwunna, 2011).

Thus, with the civil war machines silenced in January 1970, the task of rebuilding the war broken nation commenced. One of the key strategies adopted by the Gown government was the immediate takeover of all schools which were formerly owned and operated by Christian missions, and other voluntary agency groups. With this policy in place, the management and ownership of all mission schools got planted into the hands of the government. Missionaries who formerly took full charge of their different schools were totally flushed out of the system. As it were, the introduction of this takeover policy opened the cankerworms which infested schools and students with abject indiscipline and moral decadence, and impacted the quality of education provided in schools. The end result was that students' performances at examinations dropped (Arinze, 1982; \& Ezeh, 1994). 


\section{Transportation and Communication Challenges}

The area of transportation was another crucial area of difficulty encountered by Christian mission school projects in Igboland. It goes without saying that without adequate provisions for mechanized transport system, movement of the missionaries from one local community to the other suffered terrible troubles. Having arrived Igboland for the first time on $5^{\text {th }}$ December, 1885 in tiny boats, without motorcycles, cars, or even bicycles, while movement from one rural community to another proved really tough. Transportation of goods and services experienced terrible setbacks and suffered untold delays. Ability to reach out to other communities as at when attention was needed became real nightmares (Ekechi, 1996; Iwunna, 2009; \& Iwunna, 2011).

To that effect, movement from, for instance, Onitsha to Owerri, which should have taken a few brief hours by car, took some days to cover. Even at that, movement from Onitsha to Aba, Okigwe, Mbaise, and Umuahia proved even more hectic, and kept the helplessly trekking on bush tracks and other road links for several days. The implication was that precious hours of viable school hours were lost. Delivery of educational materials was delayed unnecessarily, while personnel movement was hampered. However, the situation changed over the years as British companies such as the UAC began to import motor vehicles into Igboland (Iwunna, 2009; \& Iwunna, 2011).

\section{Factors of Local Resistance}

Among the Igbo, it has been claimed that local resistance to missionary educational activities took several forms. As it were, these attitudes of resentment often came in the forms of inter-community conflicts, deliberate refusal of children's enrolment into schools, withdrawal of children and wards from mission schools, serious animosity against white missionaries, local protest matches, refusal to pay local levies in support of missionary education, interdenominational conflicts among Christian missions, refusal to donate parcels of family land for mission school projects, etc. In some cases, parents refused to pay the tuition fees of their children, as a way of forcing them to withdraw (Isichei, 1974; Odoemene, 1985; Iwunna, 2009; \& Iwunna, 2011).

Faced with these huge local obstacles, the light of missionary education was blown off in a number of Igbo communities. Children's enrolment figures dwindled in schools. Mission schools were often destroyed by local resistance forces. School projects were often denied the crucial local community support needed. Illiteracy rates grew higher in some communities. In the light of these developments, missionary efforts to push school projects ahead in some towns and villages experienced forms of kwashiorkor growth and dilapidating development.

\section{Language Obstacles}

At the earliest days of arrival on the shores of Igboland, the Christian missionaries had no knowledge of the local language of the Igbo. They could neither write nor speak this indigenous language which knowledge they needed for the educational and evangelization projects. In the meantime, they were left with the option of hiring local interpreters who assisted them communicate with the illiterate local population in their mother language (Walls, 2002).

As it were, the colonization of Nigeria by the British government received an official seal of approval at the end of the 1884/1885 Berlin Conference where fourteen European nations, plus the United States of America convened to settle their strategies for the political, economic, and social exploitation of the African continent. ${ }^{1}$ Following the conclusion of that historic conference, Nigeria became a British colonial territory, while the imposition of the Queen's language was put in place as the official medium of official protocol, including the education of the natives (Omolewa, 2006).

With the English language as the basic language of formal education, missionary educational curricula were clothed in pure European clothes with colorations of imperialism. The educational curricula became a reflection of Europe-based contents, to the extent that it was acceptable to teach children lessons about the Queen of England, the seasons of Europe, the major European wars, etc. At the same time, they deliberately ignored local historical landmarks and their relevance to the education of learners. As it were, the Igbo did not swallow that bitter pill smoothly.

The publication of the 1925 Memorandum on Education, which was Nigeria's first educational policy, however became an attempt to give the local language its proper place in school education of children. By this policy approach, Igbo language began to be used as children's language of education, starting from junior classes (The Advisory Committee on Native Education in the British Tropical African Dependencies, 1925, March, p. 4). However, the use of English as learners' language of education denied Nigerian children the opportunities of mastering the skills of reading and writing their mother languages effectively. On the part of teachers, the use of

\footnotetext{
${ }^{1}$ Unfortunately, the historic Berlin Conference was convened and concluded without inviting any kinds of representatives or representations from Africa. Empowered by the terms of the agreements reached at the conference, the British government became the largest shareholder, having won more territories, and gained political and economic dominion over the peoples and resources of its huge estates all over the continent. As it were, the need for raw materials formed the major driving force behind European colonial missions in Africa, which at the long run laid the foundations for the culture of dependence on the Western world for solutions to Africa's numerous problems.
} 
the white man's language in school education impacted their abilities to deliver the core contents of their class lessons professional, owing to their poor knowledge of English. The implication was that these two major circumstances affected children's educational empowerment and literacy skills, which to a large extent created teams of educated illiterates. ${ }^{1}$ Iwunna (2009b) defines this category of school graduates as "half baked school leavers."

\section{Health Hazards}

As it were, the health hazards posed by malaria fever, typhoid, dysentery, and dengue fever, etc. impacted the educational exploits of Christian missionaries in Igboland and other parts of Nigeria. Faced with persistent bites of virus infected mosquitoes, the missionaries could not resist the dangers and traumas of terrible ill health every now and then.

Terrible environmental situations, poor housing conditions, difficult travelling terrains, attacks of dangerous animals, and poor food conditions complicated their health situations, and often resulted in deaths. Knocked down by the effects of bad health conditions, the affected missionaries got bedridden for countless days. In the face of these circumstances, their parish work, school activities, and official educational engagements suffered terrible setbacks (Jordan, 1949: \& Osokoya, 2015).

Local school children and their teachers were not exempted from these health hazards. It then goes without saying that health failures also forced this calibre of persons away from school activities over periods of time. That being the case, children's performances at school remained in serious jeopardy, while their abilities to climb higher heights educationally could grind to some sudden halt. As it were, if proper medical treatments were not provided with speed, death often ended the game (Iwunna, 2009).

Without doubt, these health related compliucations impacted the growth of missionary education in parts of Igboland over the years. However, with the growth of the Catholic mission's investments in different sectors of community development in Igboland, their commitment in the areas of healthcare services gave birth to the establishment of clinics, hospitals, and maternity homes in local communities.

\section{Conclusions}

Just like the Igbo say in our common parlance, we have literally travelled a long journey, and arrived home finally. We are tired, but still strong. It is the time to say - 'nnoo'. Welcome back to roost. As it were, we have now come to the summation and conclusion phase of our analysis. We have no better language of delivering our results, other than to state in clear terms that the growth and spread of the Catholic missionary education in parts of Igboland, just like their other denominational counterparts who were also involved in the project, was impinged by the emergence of a number of fundamental bottlenecks, for which the mission was largely unprepared.

Faced with the problems, educational development encountered malnourished growth. The quality of its curricula contents became shallow, while teachers' professionalism in the delivery of lessons grew stunted roots, with the end result that the core objectives behind this colossal missionary project could not be fully realized, which in some cases denied their recipients the enablement to embrace their indigenous traditional values to its fullest.

However, it must be appreciated that in spite of the numerous landmines which lay along their routes of educational empowerment of the Igbo, the mission remained undaunted and undefeatable, but rather continued to gain strength and motivation to forge ahead. It was their spirit of commitment and ability to rise to the challenge of the time that resulted in the huge progress made by this mission in the overall education of the Igbo, which earned it the rank of the highest investor in the educational development of Igboland. Till date, the numbers of its schools still speak for themselves.

\section{References}

Afigbo, A.E. (2001). Igbo enwe eze: Beyond Onwumechili and Onwuejogu. Okigwe: Whytem Publishers Nigeria.

Arinze, F.A. (1982). The impact of Christian education at present. Onitsha: Archdiocesan Secretariat.

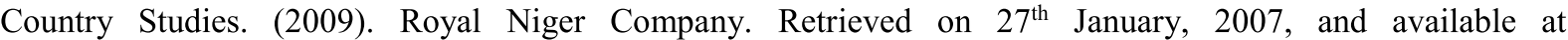
http://www.country-studies.com/nigeria/royal-niger-company.html

Depaepe, M.. Debaere, F.; \& Van Rompaey, L. (1992). Missionary education in the Belgian Congo during the colonial period (1908-1960). Neue zeitschift fur missionswissenscaft. Nouvelle revue de science missionaire, 48(4), 265-280.

Depaepe, M. (2008). Belgian images of the psycho-pedagogical potential of the Congolese during colonial era

\footnotetext{
${ }^{1}$ The term 'educated illiterates' refers to schools leavers who lacked the literacy skills needed to read and write their mother tongues perfectly, as well as white man's language - English.
} 
(1908-1960), pp. 1-18.

Ekechi, F. K. (1972). Missionary enterprise and rivalry in Igboland, 1857-1914. London: Frank Cass.

Ekechi, F.K. (1989). Tradition and transformation in Eastern Nigeria. A sociological history of Owerri and its hinterland, 1902-1947. Kent: The Kent University Press.

Ekechi, F.K. (1996). Missionary enterprise and rivalry in Igboland 1857-1991. Lagos: Minaj Publishers.

Ezeh, P. (1994). Legislation, university education and economic performance: The Nigerian experience. In: W. Tulasiwics \& G. Strowbridge (Eds.). Education and the law: International perspective. London: Routledge.

Fafunwa, A.B. (1974). History of education in Nigeria. London: George Allen \& Unwin.

Iwunna, P. (2003). Women's education and the development of Nigeria. (A Masters degree thesis submitted at the Faculty of Psychology and Educational Sciences, Katholieke Universiteit Leuven, Belgium, pp. 1-71.

Isichei, E. (1974). A history of the Igbo people. Enugu: Nsukka University Press.

Iwunna, P. (2009). The impact of the Christian missionary education on the educational development of Nigeria. A case study of the primary school educational activities of the Catholic Mission in Igboland (1925-1970). (A doctoral dissertation submitted to the Faculty of Psychology and Educational Sciences, Katholieke Universiteit Leuven, Belgium), pp. 1-330.

Iwunna, P. (2009b). School textbooks as tools of evangelization in Catholic Mission schools in Igboland, Nigeria (1925-1960). An analysis of key images. In: A. Van Gorp \& M. Depaepe (Eds.). Auf der Suche nach der wahren Art von Textbuchen. Beitrage zur historischen und systematischen schulbuchforschung (81-97). Bad Heilbrunn: Julius Klinkhardt.

Iwunna, P. (2010). Textbook illustrations as tools of educational reenforcement in Catholic primary schools in Igboland, Southeast Nigeria (1925-1960). In: C. Heinze \& E. Matthes (Eds.). Das bild im schulbuch. Beitrage zur historischen und systematischen schulbuchforschung (219-231). Bad Heilbrunn: Julius Klinkhardt.

Iwunna, P. (2011). The impact of the Catholic primary school education in iGboloand: The impact of the Catholic education. Saarbrucken: LAP Lambert Academic Publishing GmBh \& Co. KG.

Jordan, J.P. (1949). Bishop Shanahan of southern Nigeria. Dublin: Clonmore \& Reynolds.

Kalu, O.U. (1971). The embattled gods. Christianization of Igboland, 1857-1914. London: Frank Cass.

Kalu, O.U. (1986, February). Primitive Methodists on the railroad junctions of Igboland, 1910-1931. Journal of Religion in Africa, 16(1), 44-66.

Madiebo, A.A. (1980). The Nigerian revolution and the Biafran war. Enugu: Fourth Dimension Publishers Co. Ltd.

Macrae, N.C. (1956). The book of the first sixty years. 1895-1955 Hope Waddell Training Institutions. Calabar: Hope Waddell Press.

National Archives, Enugu. (1925, June). Memorandum. Roman Catholic Mission at Orlu. M.P. No. 640/14/1925. OW: 277/24 RIVPROF 8/12/245.

National Archives, Enugu. (1944, August). Report on Uyo Elementary Training Centre. By Mr. T.H. Baldwin, Chief Inspector of Education, Southern Provinces. In: Inspection Notes on Uyo Elementary Training Centre, 1936-1946. CP. 2974. CALPROF. 3/1/2636.

Nwosu, V.A. (1982). The growth of the Catholic Church in Onitsha Ecclesiastical Province. In: A.O. Makozi \& G.J.A. Ojo (Eds.). The history of the Catholic Church in Nigeria (38-54). Lagos: Macmillan Nigeria Publishers Limited.

Nwosu, V.A. (1990). The laity and the growth of the Catholic church in Nigeria. The Onitsha story 1903-1983. Onitsha: Africana-FEP Publishers Limited.

Odo, C.O.; Ede, F.E.; \& Ezike, B. (1996). History of education. A handbook. Enugu: Calvaryside Printing \& Publishing Co.

Odoemene, S. (1985). Research on the coming of the early Christian missionaries in Ahiara. (A research paper submitted at the Faculty of Education, University of Jos, Nigeria), pp. 1-61.

Ogoko, A.O.M. (2006). The African personality in a mal-functional society: Implication for an African philosopher. Oche Amamihe. Wisdom Journal of Theology and Philosophy, 1(3), 92-104.

Omolewa, M. (1986). Certificate history of Nigeria. Ikeja: Longman Nigeria Limited.

Omolewa, M. (2001). The challenge of education in Nigeria. Ibadan: University Press.

Omolewa, M. (2006). Educating the "native": A study of the education adaptation strategy in British colonial Africa, 1910-1936. The Journal of African American History, 91(3), 267-287.

Omolewa, M. (2008, February \& April). Programmed for failure? The colonial factor in the mass literacy campaign in Nigeria, 1946-1956. International Journal of the History of Education. Special Issue: Technologies of the word: Literacies in the history of education, 44(1\&11), 107-121.

Onah, J.N. (1998). Problems and prospects of primary education. In: A.B.C. Ugwu \& A. Omalle (Eds). Introduction to primary educational studies (111-118). Enugu: Fred-Ogah Publishers.

Osokya, I.O. (2015). Teaching and researching History in Nigeria. Ibadan: Laurel Educational Publishers. 
Ozigbo, I.R.A. (1985).Igbo Catholicism. The Onitsha connection 1967-1984. Onitsha: African-FEP Publishers Limited.

Omenka, N.I. (1989). The school in the service of evangelization. The Catholic educational impact in eastern Nigeria, 1886-1950. Leiden: E.J. Brill.

Phillipson, S. (1948). Grants in aid of education in Nigeria. A review, with recommendations. Lagos: Government Printer.

Seghers, M. (2004, August). Phelps-Stokes in Congo: Transferring educational policy discourse to govern metropole and colony. Paedagogica Historica, 40(4), 455-477.

Taiwo, C.O. (1980). The Nigerian education system. Past, present \& future. Lagos: Thomas Nelson (Nigeria). Limited.

The Advisory Committee on Native Education in the British Tropical African Dependences. (1925, March). Education policy in British Tropical Africa. (Available at the Library of the National Museum Lagos).

Ugwu, A.B.C. \& Nwamuo, C.N. (1998). Administration and management of primary education in Nigeria. In A.B.C. Ugwu \& A. Omalle (Eds.). Introduction to primary education studies (1-11). Enugu: Fred-Ogah Publishers.

Zachernuk, P.S. (1998). African history and imperial culture in colonial Nigerian schools. African Journal of the International African Institute, 68(4), 484-505. 